\title{
Contribution of Mara junior science college recitation program implementation process
}

\author{
Mohd Sahandri Ghani Hamzah ${ }^{1, *}$, Noor Fadilah Ambo ${ }^{2}$, Saifuddin Kumar Abdullah ${ }^{2}$ \\ ${ }^{1}$ Universiti Pendidikan Sultan Idris, Tanjung Malim, Malaysia \\ ${ }^{2}$ Department of Polytechnic Education, Ministry of Higher Education, Malaysia
}

\section{A R T I C L E I N F O}

\section{Article history:}

Received 8 September 2016

Received in revised form

27 October 2016

Accepted 8 November 2016

\section{Keywords:}

Implementation

Recitation program

MJSC

\begin{abstract}
A B S T R A C T
This working paper is intended to evaluate the contributions of the Recitation Program process among four MARA Junior Science College students in Perak state based on the CIPP Model. The study design is a descriptive study which comprised students from three MARA Junior Science Colleges in Perak i.e. MARA Junior Science College Felda, MARA Junior Science College Pasir Salak and MARA Junior Science College Taiping. A total of 240 students were selected as study samples through convenient random sampling. Data was obtained from questionnaire forms and processed using Statistical Package for Social Sciences (SPSS) version 17. Results of multiple regression tests showed that four predictors contributed 13.3 per cent. The major predictor which contributed the most was student objectives with a contribution of 6.8 per cent, the second largest predictor was planning which contributed 3.5 per cent, while the third largest predictor that is student tasks and enrichment activities contributed 2.10 per cent and the last predictor, student strategies and recitation methods contributed 0.90 per cent. These findings revealed the possibility that there could be several other factors which affected or influenced the impact on student conduct, which was not accounted for in this study. On the whole, there are three main recommendations which look at the role of the management and administrator, the role of the teachers and students which require mutual cooperation for this program to succeed. In conclusion, a more comprehensive evaluation on implementation needs to be conducted to produce consistent results.
\end{abstract}

(C) 2016 The Authors. Published by IASE. This is an open access article under the CC BY-NC-ND license (http://creativecommons.org/licenses/by-nc-nd/4.0/).

\section{Introduction}

MARA Junior Science College (MJSC) is one of the secondary educational institutions within the purview of the Council of Trust for Indigenous People (MARA), an agency of the Ministry of Rural and Regional Development. The establishment of MJSC indirectly equipped fully residential science schools of the Ministry of Education. Sessions for student intake comprise form one and form four students who fulfil entry requirements.

MJSC was established under the Council of Trust for Indigenous People Act No. 20, 1966 as a commitment to achieve MARA goals in the field of training and education. MJSC was set up to provide education at secondary and pre-university levels in

\footnotetext{
* Corresponding Author.

Email Address: sahandri@fppm.upsi.edu.my (M. S. G. Hamzah) https://doi.org/10.21833/ijaas.2016.11.011

2313-626X/@ 2016 The Authors. Published by IASE.

This is an open access article under the CC BY-NC-ND license

(http://creativecommons.org/licenses/by-nc-nd/4.0/)
}

the fields of science and technology to Bumiputera students with high mental abilities. MJSC education will familiarize students with education based on science and an aspect of Malaysian culture which will foster long-lasting physical, spiritual and intellectual development and to produce students with critical thinking, creative, and healthy with breadth and depth besides having a high spirit of patriotism and nationalism.

The Monitoring Committee Meeting of the MARA Secondary Education Division No.: 5/2011 dated 15 June 2011 reached a decision that MJSC Muslim students were required to memorize at least one part (30 parts) for lower secondary students and four selected suras ${ }^{\dagger}$ (As-Sajadah, Al-Insan, Yaasin and Al-Mulk) for upper secondary students.

To ensure the success of this program, the school is allowed to use monetary contributions should additional teachers be required for reciting (reading

† sura: a chapter or section of the Quran 
aloud recitations) students' readings. Therefore, the following lists the objectives of the program:

1. Develop and educate students toward excellence and glory.

2. Reach out to students with the Quran to produce smart and obedient students.

3. Imbue a college atmosphere which continuously enculture the Quran in life.

The target is all form one to form five MJSC students throughout Malaysia. The contents of the syllabus are as follows:

Lower secondary has 30 parts

1. Form one: An-Nas to Ad-Dhuha suras (common suras)

2. Form two: Al-Lail to Al-Mutaffifin suras

3. Form three: Al-Infitar to An-Naba' suras

Whereas upper secondary comprises selected suras such as:

1. Form four: as-Sajadah and al-Insan suras

2. Form five: Yaasin and Al-Mulk suras

According to the circular, the time for recitation is three times a week between Maghrib and Isha*. However, it depends on the respective MJSCs to determine how the program is implemented. Therefore, the suggested implementation method for this program is as follows:

-Students are separated into groups.

- Each group consists of only four or five persons.

-Each group is led by a student.

- At least one teacher takes turns to conduct monitoring during the recitation program.

- Students recite using the Huffaz method i.e. 60 repetitions of each verse in parts.

The Huffaz method entails the teacher reading with correct articulation to the student before the student begins reciting or the student reads aloud in front of the teacher first before beginning the recitation to ensure correctness and Tajweed in reading. The student will repeat a verse/the first part of a verse in sixty repetitions (60 times). The student is required to look at the Quran in the first five repetitions. In the sixth to the tenth repetition however, the student is required to close the Quran. This is carried on with five times of repetition with the Quran closed. The total number of closing and opening of the Quran is sixty times. After completion, recite verse/second part of verse using method number 1 and 2 .

\section{Statement of the problem}

Recitation requires students to devote their full attention because they need to read many times.

\footnotetext{
* Maghrib: When the sun has completely set beneath the horizon. Isha: Night time after Maghrib.
}

After observing and interviewing the students, the researchers found that generally there were four problems encountered by the students in this program.

One is required to read with Tajweed, correctly and accurately while reading the Quran. Despite this, the researchers found that after conducting the Quran reading screening tests only $47 \%$ of the students could read the Quran fluently, 36\% were average and $17 \%$ were not fluent and had not mastered the way of reading with Tajweed. Therefore, they required a guide to be able to read correctly. Nevertheless, there are monitoring teachers on duty assumed to serve as student guides too however they are also weak in their reading. This statement parallels the views of Mohd Yusoff and Saidi (2008) who stated that failure to read the Quran well and excellently bring undesirable effects on the Muslim individual. Among the undesirable effects are invalidity of worship and not perfecting other religious obligations which concern reading of the Quran and this indirectly means that the individual does not honor the Quran as laws and ethics laid down in the reading of the Quran have been violated; which was also asserted by ElMuhammady (1994) that reading the Quran correctly is important in order to determine whether the religious obligations performed was valid or invalid.

In this regard, if students wished to attain skills to read the Quran correctly, they had to read continuously from time to time. The time to read and recite also needs to be taken into account whether it is appropriate and does not interfere with specified academic times. In this case, the researchers found that the students did not have much time to recite and read aloud verses or recite suras in front of the teacher. It was only during the allotted period between Maghrib and Isha. This problem makes it quite complicated for the students to recite with the burden of existing MJSC activities i.e. either academic or non-academic activities. Therefore the school management needs to set aside time for the students to read or memories the Quran. The teachers involved must also be trained in reading the Quran and have the skills to read correctly because the teachers involved will identify and correct the students' reading. Likewise, teacher preparedness, the same as the students are not taken into account whether they are ready to teach or recite (listen to students' recitation of verses) as the existing burden of teachers in schools also clearly influences the teachers' preparedness.

The researchers were compelled to conduct a study on the program based on implications from the above situation. It is evident that the uniqueness of this program needs to be examined because the students' pure science backgrounds and the main objective of the school differed from the involvement of Maahad Tahfiz in this recitation program. There are five implementation aspects which will be examined - the first aspect is the student objective during recitation i.e. their ability to recite within a 
stipulated time, the ability to recite the As-Sajadah and Al-Insan suras. While the second aspect is the student planning which will be examined such as before, during and after recitation. The third aspect is student strategies and methods of reciting and retaining verses which have been recited. The fourth aspect is the student tasks and enrichment activities such as tasks during training, listening and reviewing a friend's reading and reading aloud in front of a friend(s) and the last aspect is the program's impact on the students, to become disciplined students such as disciplined, ethical and proper in conduct. On the whole, the aim of this study is to look at the success of implementing the program on the students employing the theoretical learning approach by Edward L. Thorndike (18741949). He introduced 'trial and error learning' in this theory, and the three laws of learning i.e. the law of readiness, law of exercise and law of effect.

\section{Methodology of study}

This study is a descriptive study and its purpose is to evaluate the implementation of the recitation program at MJSC in the state of Perak. According to Konting (2009), descriptive study is a study aimed at explaining a phenomenon that is happening as well as to explore a field that has yet to be studied or less studied. On the other hand, Noah (2003) defined descriptive study design as usually undertaken with the intention of providing systematic explanations regarding facts and characteristics of a certain population or field of interest, factually and accurately. The instrument of this study was developed based on previous studies conducted and expert opinion was also sought from educational intellectuals in Malaysia concerning the implementation of this recitation program. Questionnaires were used in this study. They were distributed to form four students as well as those distributed personally by the researchers themselves to the students concerned. In this way, the researchers could evaluate the implementation of the recitation program on the MJSC students.

\subsection{Population and study sample}

The population of this study comprised students from three MJSCs in Perak state i.e. MJSC Felda, MJSC Pasir Salak and MJSC Taiping. The study population consisted of form four male and female, Muslim students who are currently enrolled in the Quran Recitation Program as stipulated by the Islamic Education and Arab Language Unit, MARA Secondary Education Division (SED).

\subsection{Sampling method}

The sampling method used in this study was the convenient random sampling method using the numbering system in the attendance record book by selecting the odd numbers of student attendance.
The maximum number of students in a class was 30 and the number of classes involved was seven. Based on the student attendance record book, the overall random total in a class numbered 15 with the overall total for a school corresponding to 105 .

The total number of respondents from the three MJSCs was estimated at 315 respondents. This method is the process of taking or using samples where each individual in the population has an equal chance of being selected (Konting, 2009). The researchers selected form four students from MJSC Felda, MJSC Pasir Salak and MJSC Taiping using convenient random sampling. Employing the convenient random sampling technique will enable an individual to have an equal chance of being tested.

\subsection{Study instrument}

The instrument used in this study is a questionnaire developed by the researchers to examine the status of implementation of the MJSC Quran Recitation Program in Perak state through developing an instrument by way of an Instrument Specification Table (IST).

\section{Results of study}

Multiple regression tests were used stepwise to answer the research questions and to test significant contributions of independent variables (objective, planning, strategies and methods including tasks and enrichment activities) on the impact of student conduct. Before multiple regression tests could be conducted several assumptions which became test preconditions were examined. The preconditions that needed to be fulfilled were adequate sample size, absence of isolated data, absence of multicollinearity problems and singularity and normal distribution, linear as well as having equality of variances or homoscedasticity (Pallant, 2001; Muijis, 2014; Coakes, 2005). The normal distribution is as shown in Fig. 1.

After the preconditions have been fulfilled as depicted in Fig. 1, then regression tests involving six predictor variables (objective, planning, strategies and methods including tasks and enrichment activities) and the impact on student conduct as the criterion variable were conducted. Analysis of variance in the regression clarified whether the model developed produced a sound predictor with regards to the significance of the predictor which was developed. It tested the difference which existed between the dependent and independent variables.

In this regard, Table 1 elaborates the results of the analysis of variance to identify the $F$ value with the significant value, $\mathrm{p}<0.05$.

Therefore, results of the analysis in Table 1 showed that the $F$ value $=7.208$ and its significant value $=(\mathrm{p}<0.05)$.

Results of the multiple regression analysis stepwise which identified the relative contributions of six independent variables on the impact of student conduct is summarized in Table 2 . 
Multiple regression analysis (stepwise) in Table 2 shows independent variables objective, planning, strategies and methods including tasks and enrichment activities are predictors with contributions $(13.3 \%)$ of significance $(\mathrm{p}<0.05)$ toward the impact on student conduct for the study population (sample size $=242$ ).
Results of the study showed a correlation between the dependent variables (impact on student conduct) and the overall group of independent variables of 0.112 ( $R$ multiple). Rate variance in the dependent variables that was significantly associated with all the independent variables can be explained by the power of the regression model with the value (R2) of 13.3 per cent.

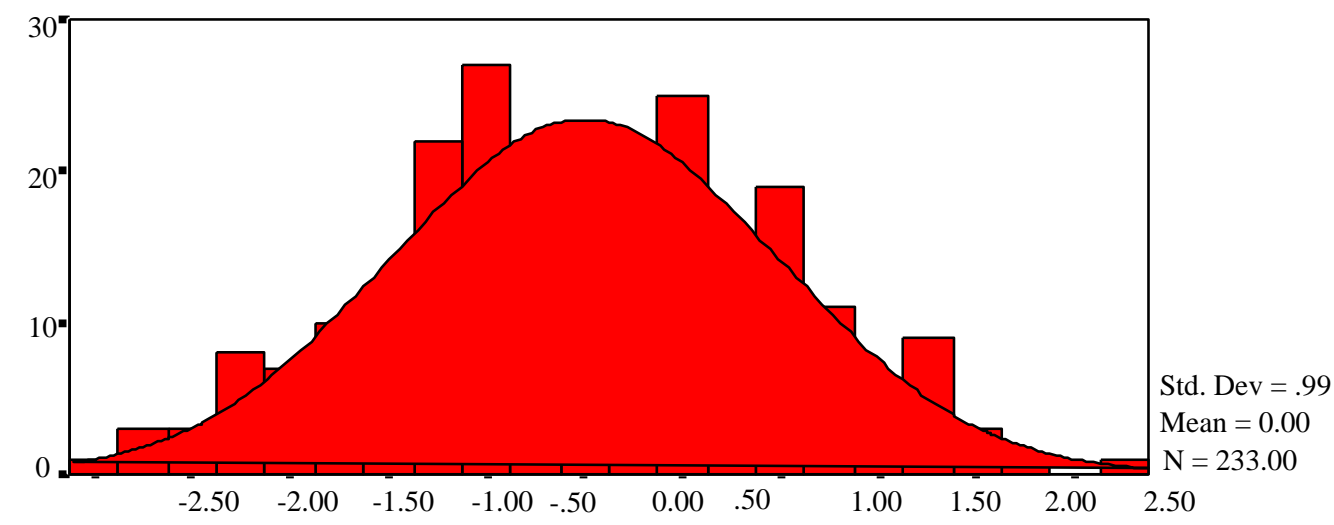

Fig. 1: Normal Distribution of IMPAK dependent variables

Table 1: Analysis of variance

\begin{tabular}{|c|c|c|c|c|c|c|}
\hline Model & & Sum of Squares & $\mathrm{df}$ & Mean Square & $\mathrm{F}$ & Sig. \\
\hline \multirow{3}{*}{4} & Regression & 4.200 & 4 & 1.050 & 7.208 & $.000_{(d)}$ \\
\hline & Residual & 33.214 & 228 & .146 & & \\
\hline & Total & 37.413 & 232 & & & \\
\hline
\end{tabular}

Table 2: Multiple regression analysis (Stepwise)

\begin{tabular}{|cc|c|c|c|c|c|}
\hline Variable $(\mathrm{x})$ & $\mathrm{B}$ & $\mathrm{B}$-ta & $\mathrm{R}$ & $\mathrm{T}$ & $\mathrm{S}$ & Contribution (\%) \\
Objective & 0.185 & 0.172 & 0.068 & 2.279 & 0.024 & 6.80 \\
Planning & 0.149 & 0.166 & 0.090 & 1.899 & 0.059 & 3.50 \\
\hline $\begin{array}{c}\text { Strategies and methods } \\
\text { Tasks and enrichment activities } \\
\text { Constant }\end{array}$ & -0.121 & -0.150 & 0.97 & -1.835 & 0.068 & 0.90 \\
\hline & 0.112 & 0.162 & 0.112 & 1.997 & 0.047 & 2.10 \\
\hline
\end{tabular}

R: 0.335, R Squared: 0.112, R Squared unadjusted: 0.016, Constants: 1.968, Standard error: 0.191

The main and highest predictor for impact on student conduct in implementing the recitation program at MJSCs, Perak state was the student's objective in reciting $(\beta=0.172, \mathrm{t}=2.279$ and sig- $\mathrm{t}=$ 0.024) which contributed 6.80 per cent. This situation can be shown when the objective score of the students in reciting increased by one unit causing the impact on student conduct to increase by 0.172 units. While the second most important predictor which contributed 3.50 per cent was planning $(\beta=0.166, t=1.899$ and sig- $t=0.059)$ which contributed 3.50 per cent. In other words, when the students' planning score in reciting increased by one unit it caused the impact on student conduct to increase by 0.166 units and the third most important predictor were tasks and enrichment activities $(\beta=0.162, \mathrm{t}=1.997$ and sig- $\mathrm{t}=$ $0.047)$ which contributed 2.10 per cent. This means that when the scores for student tasks and enrichment activities in reciting increased by one unit it caused the impact on student conduct to increase by 0.162 units.

Student strategies and methods $(\beta=-0.150, \mathrm{t}=$ 1.835 and sig-t $=0.068$ ) in implementing the recitation program formed the fourth and last predictor which had an effect and contributed 0.90 per cent toward impact on student conduct. This showed that when student strategies and methods increased by one unit, the impact on student conduct increased by -0.150 unit. This showed that student strategies and methods also played a role in contributing to the impact changes on student conduct in the implementation of the MJSC recitation program in the state of Perak.

These findings revealed the possibility that there could be several other factors which affected or influenced the impact on student conduct which were not mentioned in this study (Pallant, 2001).

The value of adjusted R2 provided an estimate with regards to the extent in which this model matches with other data sets from the same population. Its value is in the range of 0.0 to $1.0 \mathrm{in}$ evaluating the fit regression model or suitable (fit) with the data. The value of adjusted $\mathrm{R} 2<0.1$ is weak (not good), $0.11-0.3$ is low, $0.31-0.5$ is average and $>0.5$ is robust (good). Given that the value of adjusted R2 in this study was 0.191 . Therefore the resultant model was characteristically low. The regression equation for this study is as follows: 
Impact $=x+X 1+X 2+X 3+X 4$

where;

$x=$ constant

$X 1$ = objective

$X 2=$ planning

$X 3=$ strategies and methods

$X 4=$ tasks and enrichment activities

therefore,

Impact $=1.968+0.185 * X 1+0.149 * X 2-0.121$

$$
* X 3+0.112 * X 4
$$

\section{Discussion and summary}

\subsection{Objective}

Based on the analysis in Chapter 4, the study found that most students did not set their objective in reciting as-Sajadah and al-Insan suras. They only recited according to requirements i.e. following teachers' instructions without continuing further. If there is no prompting from the teachers, the students did not feel the need for them to recite the suras that have been set. The study also found that most students could only recite a maximum of only three to four verses for each recitation session. Students who have no religious school backgrounds and never studied or completed reading the Quran also need to be taken into account. These factors could also possibly contribute to the percentage of students who do not set their objective when reciting.

Results of findings in this study are supported by Rita O' Donoghue (2005-2006) who stated that students who have an objective in learning motivate themselves. Since $49.4 \%$ to $56.5 \%$ of the students did not set their objectives during recitation, the mean level obtained was average resulting in them not being able to achieve the objective of reciting the as-Sajadah and al-Insan suras according to the targeted stipulated time.

\subsection{Planning}

The study also found that students did not have a specific plan either, before, during and after reciting. They were also not consistent in planning such as not using the whole recitation suras sourced from the Ottoman tradition of the Quran, and did not practice reading whole recitation verses/sentences and so on.

Nevertheless, this study contradicts the findings of a study by Pinto and Prescott (2007), that planning is crucial to ensure the successful implementation of a program. According to Pelnekar (2011), planning is a process to identify the objectives of a program.

Thus, the absence of a specific plan would mean that students are unable to set their recitation objective according to the targeted specified period.

\subsection{Strategies and methods}

It was revealed that students also implemented less of the strategies and methods commonly used by a Quran hafiz and a pathetic issue was that there were also some students who did not have strategies in reciting even though strategies and methods are very crucial for a person to achieve the objective set.

These study results paralleled the findings by Dunlosky et al. (2013) who found that the use of tools in learning can assist students in enhancing their cognitive and educational psychology. Nevertheless, students in this study did not use suitable methods which resulted in a decline in their cognitive and psychological levels during recitation.

\subsection{Tasks and enrichment activities}

Tasks and enrichment activities are also no less important. This process can help students to recall the verses recited and could assist in their reading fluency. Based on the analysis in Chapter 4, the students preferred to recite individually without pairing, which was easier for them to mutually recite the verses which have already been recited between each other. Perhaps there is less time to recite, or daily routine is too jammed packed with activities or other factors such as personal problems and their non-religious school backgrounds before entering MJSC - all these also contribute to the students' weakness in performing tasks and enrichment activities.

In this regard, findings of this study corresponded to the findings of Jablon and Wilkinson (2006) which proved that the existence of student enrichment activities can assist them in learning. Although the students did not have a specific objective nor careful planning or using strategies and methods earnestly; however, tasks and enrichment activities can assist them in reciting. In this study, the students were more inclined to recite alone as compared to in pairs and usually most reciters recited, alone.

\subsection{Impact}

This study found that the students had yet to achieve their ability in ethical conduct. They can only behave in a disciplined and proper manner. The researchers viewed that disciplined conduct involves reward and punishment. For instance, if students come in late for class, they will be punished by the class teacher. On the other hand, praise will be given to those who come early. Whereas the ability to behave properly could be driven by how they are taught at home and not due to this program which contributed to a high mean.

The ability to behave in a disciplined and proper manner corresponds to the findings by Ramsay and Richards (1997) who found that cooperative learning can create a positive impact on the students because reciting the Quran in this program has cooperative learning characteristics as students can 
recite in groups or pairs. Nevertheless, there were students who chose to recite alone which could contribute to the reason why some students lacked the ability of ethical conduct.

This program was implemented to produce students who are not only smart but who can be obedient human beings in facing lives' challenges in this world and able to balance demands in the afterlife. There are a few issues in this implementation which needs to be improved in order for the program to actually produce students who are smart and obedient.

\subsection{Recommendations}

Recommendations in this study refer to three main parties, namely the role of the management and administrator, the role of the teachers and the role of the students, themselves.

\section{Role of management and administrator}

With reference to the report of the results analysis in Chapter 4, the students' mean in strategies and methods in reciting was very weak. Most of them only repeated their readings without using recitation tools or facilities in school because of the problem of shortage of teachers or drawbacks in the facility itself.

1. The role of the management is crucial in conducting a program in order to assist the program to run smoothly. Among factors that need to be taken into consideration include finance, access to student facilities to recite, and the time for them to recite. The researchers proposed that the management sets aside a special budget specifically for this program as mentioned by headquarters and as stated in a related circular.

2. The financial aspect becomes increasingly important because the program requires religious teachers from outside MJSC to assist in student recitations and to teach students who are still weak in their reading. The inadequate number of religious teachers could jeopardize this program in the long term. This is because the existing number of teachers have already committed to students who will be sitting for major examinations such as PMR and SPM. Therefore, it is suggested that the administrators extend their cooperation to provide a special budget for this program.

3. In addition, the lack of access to facilities is also identified as the cause of students' difficulty to recite. If copies of the Quran are inadequate, it is feared that the students would be unmotivated to recite. Apart from that, the ventilation conditions where the students conduct recitations i.e. at the Surau* which is quite warm could prove uncomfortable. Therefore, it is suggested that the management install air conditioners or increase

\footnotetext{
* Surau is an Islamic assembly building in some regions of Sumatra and the Malay Peninsula used for worship and religious instruction
}

the number of fans to provide comfort for students to conduct recitations.

4. As the main curriculum of MJSC is in the field of science, therefore special credit hours for reciting do not exist. In this regard, the time allotted to recite i.e. between Maghrib and Isha was found to be insufficient. During that time, the students and also the teachers are required to do recitations. Therefore, it is recommended that the management together with the timetable management unit allocate credit hours for this program in the timetable to facilitate the implementation of the program.

5. The researchers also suggested that the management provide special certificates to students who have successfully recited the suras set by the Secondary Education Division (SED). It is hoped that with the awarding of the certificates it would perk the students' interest to continue reciting and to make early preparations to recite the suras for next year's syllabus without being instructed by the teachers.

\section{The role of the teacher}

1. Based on the report of the results analysis, in terms of ability in the level of achievement of student objective in reciting, the researchers found that the students' mean was average but the standard deviation in the students' ability to recite according to the targeted specified period was high compared to two other abilities i.e. ability to recite as-Sajadah and al-Insan suras. Based on the standard deviation mentioned, the level of the students' achievement in the ability mentioned was uniform (homogeneous). Therefore, it is suggested that the teachers raise the students' awareness and explain to them about the steps to formulate objectives in reciting because teachers are among the parties involved in the success of the program. It was found that most of the students did know their objective of reciting and that they also did not put in place a proper plan to recite. Apart from this, the students did not know appropriate strategies and methods to recite as well as the kinds of activities which can be conducted to retain recitations in their memory.

2. The researchers also found that the students' mean in planning was also at an average level with a mean value of 2.476 (SD 0.446) which referred to the students' mean in planning before reciting which was 2.456 (SD 0.538), the mean in planning during recitations was 2.439 (SD 0.509) and the mean in planning after recitation was 2.563 (SD 0.595). The researchers found that the students only made plans of not more than two items in the planning namely whether before planning, during or after. However, based on the standard deviation, the students have uniformity in their planning before, during and after. The researchers also suggested to the teachers to provide planning guides before, during and after recitation to the students so that they know what needs to be done during the recitation process. 
3. On the whole, the mean for student strategies and methods was at a weak level but the standard deviation was high. This showed that student strategies and methods were uniform in reading verses which were recited during prayers. As nearly $40 \%$ of the students come from nonreligious school backgrounds, whether secondary or primary, it made the situation slightly difficult for them to recite quickly. For this reason, it is suggested that teachers identify students who have this difficulty. These students need to be assisted and taught the correct way to recite because they do not have Arabic language skills.

4. The researchers suggested that the teachers inform the students regarding the importance of reciting. They need to be aware of the benefits which they will obtain not only in this world but also in the afterlife. Reciting not only sharpens their thinking but also brightens their hearts. Therefore, teachers should help students by sparking their interest in this recitation program through conducting programs such as talks, seminars, workshops, recitation competitions and etc., either at MJSC or between MJSCs in Malaysia.

5. As there are significant differences in planning before, during and after between MJSC Special Education Program (SEP) and non SEP and also in the strategies and methods of reciting among male and female students, therefore it is suggested that the teachers develop recitation modules based on high mean scores in planning including strategies and methods of reciting. Therefore it is recommended that teachers plan using the Quran of the Ottoman tradition, dividing the number of verses to be recited and reading fluently verses which have been recited, reciting individually according to the number of verses set, reading fluently the verses which have been recited and correcting errors in reading. While sound strategies and methods include participating in recitation tests at school and reading suras which have been recited during prayers.

\section{The role of the student}

The mean level of student tasks and enrichment activities reported in Chapter 4 was moderate. Similarly, the impact on program implementation was also at a moderate level because the students only behaved in a disciplined and proper manner but still lacked ethical conduct. Nevertheless, there was uniformity in the students' ethical conduct due to the high standard deviation as compared to their ability in disciplined and proper conduct.

Therefore, the researchers suggested that students perform self-reflection in order to internalize the program. This is to be conducted not merely for the sake of the program itself but also for the aim of producing students who are smart and obedient. The role played by students is crucial for the successful implementation of the recitation program. The students need to persevere in reciting because its benefits is not just for the school but will come back to the reciters, themselves.
It is also suggested that the students take the teachers' suggestions and advice as a guide to monitor the verses or suras which have been recited. Discipline in reciting can assist the students not only in life but also in academic matters. This is because students' awareness in reciting can provide a huge impact generally, on themselves and specifically, on the aims of the program.

Observing one's conduct and speech are among the ways to retain recitations in one's memory. Despite the various efforts conducted by the school, if students do not desire to help themselves then their personal aims and those of this program will not be achieved. The main drive comes from the students themselves. In this regard, the researchers found that suggestions to observe one's conduct and speech could indirectly assist in achieving the aims of the program.

\section{Suggestions for further research}

In accordance with the view of the researchers, the following three suggestions for further research which are appropriate for this title are:

The level of MJSC students' interest in reciting: Based on the analysis report in Chapter 4, most of the research questions have in response, moderate and weak student mean levels. If reference is on the MJSC students' backgrounds, they come from various differing backgrounds. Some have primary and secondary religious school educational backgrounds. On the other hand, there are also those without any religious school educational backgrounds. This can become the cause factors why objectives were not achieved because the absence of the religious school experience could cause them not to be interested in reciting. Even though there are students who have the religious school experience, however their mental and emotional levels are not ready because of their assumptions that the MJSC system of education does not require reciting the Quran already. It is suggested that other researchers seek the truth in this assumption in relation to the students' level of interest in reciting.

Contributory factors in Quran recitation achievement among MJSC students: Most MJSC students have high study skills in the field of science and mathematics. Studies to seek contributory factors in recitation achievement can also be conducted because results of this study found that students from MJSC SEP and non MJSC SEP have differences in their planning to recite. These differences may arise because of academically high cognitive level factors which could also contribute towards the success of a program. The teachers concerned or other researchers could seek out factors which contribute to the success of a MJSC student in reciting.

MJSC Ulul Albab students' recitation strategies: The report in Chapter 4 showed that most students were still weak in formulating strategies to recite and were not able to strike a balance between reciting and academic learning. Nevertheless, this 
issue did not arise in MJSC Ulul Albab. Based on the examination achievement report from the MARA Evaluation and Examinations Unit 2013, the researchers found that students from MJSC Ulul Albab had good recitation and academic achievements as compared to MJSCs that were not Ulul Albab. One of the factors of achievement of MJSC Ulul Albab in reciting was the students' mental preparedness to recite the Quran. Therefore, teachers or other researchers could study strategies employed by MJSC Ulul Albab students so that it can be used as an example by students from MJSCs that are not Ulul Albab. Studies can be conducted from all angles such as the role of the school management and administrator, the teachers and students, themselves.

\section{Conclusion}

Every weakness can be overcome if the weakness factor is found and resolved by the responsible party. The successful implementation of a program is through the efforts of all parties involved. The school management and administrator, teachers, and students need to play their roles so that all flaws in program implementation can be alleviated. Parents are also not exempted from this issue. Therefore, a more comprehensive study is required to secure consistent results.

\section{References}

Dunlosky J, Rawson KA, Marsh EJ, Nathan MJ and Willingham DT (2013). Improving students' learning with effective learning techniques promising directions from cognitive and educational psychology. Psychological Science in the Public Interest, 14(1): 4-58.
El-Muhammady AH (1994). Pendidikan Islam: Peranannya Dalam Pembangunan Ummah. Penerbitan Hikmah, Kuala Lumpur, Malaysia.

Jablon JR and Wilkinson M (2006). Using engagement strategies to facilitate children's learning and success. YC: Young Children, 61(12): 12-16.

Konting MM (2005). Kaedah penyelidikan pendidikan. Dewan Bahasa dan Pustaka, Kuala Lumpur, Malaysia.

Mohd Yusoff MYZH and Saidi BM (2008). Keupayaan bacaan al-quran di kalangan pelajar tingkatan empat: Kajian di beberapa buah sekolah menengah terpilih di negeri Terengganu. AlBayan: Journal of al-Quran and al-Hadith, Volume 6: 58-85.

Noah SM (2003). Reka bentuk penyelidikan: falsafah, teori dan praktis: sebuah buku mesra pengguna. Penerbit Universiti Putra Malaysia, Selangor, Malaysia.

Pallant J (2001). The SPSS survival manual: A stepby-step guide to data analysis using SPSS for Windows (version 10). Allen \& Unwin, Sydney, Australia.

Pelnekar C (2011). Planning for and implementing ISO 27001. ISACA Journal, 4(4):1-8.

Pinto JK and Prescott JE (1988). Variations in Critical Success Factors over the Stages in the Project Life Cycle. Journal of Management, 14(1): 5-18.

Ramsay SG and Richards HC (1997). Cooperative learning environments: Effects on academic attitudes of gifted students. Gifted Child Quarterly, 41(4): 160-168. 